\title{
Hendrina Cecilia Kruger se godsdienstige mentaliteitsprofiel in haar mistieke oordenkingsbundel (ca. 1750-1810) uit die trekboertyd
}

\author{
Author: \\ Andries W.G. Raath ${ }^{1}$ \\ Affiliation: \\ ${ }^{1}$ Research Associate, \\ Department of History, \\ University of the Free State, \\ South Africa

\section{Correspondence to:} \\ Andries Raath \\ Email: \\ raatha@ufs.ac.za \\ Postal address: \\ PO Box 339, Bloemfontein \\ 9301, South Africa \\ Dates: \\ Received: 06 Mar. 2014 \\ Accepted: 28 Aug. 2014 \\ Published: 14 Aug. 2015 \\ How to cite this article: \\ Raath, A.W.G., 2015, \\ 'Hendrina Cecilia \\ Kruger se godsdienstige \\ mentaliteitsprofiel in haar \\ mistieke oordenkingsbundel \\ (ca. 1750-1810) uit die \\ trekboertyd', HTS Teologiese \\ Studies/Theological Studies \\ 71(1), Art. \#2652, 10 pages. \\ http://dx.doi.org/10.4102/ \\ hts.v71i1.2652

\section{Copyright:} \\ C 2015. The Authors. \\ Licensee: AOSIS \\ OpenJournals. This work is \\ licensed under the Creative \\ Commons Attribution License.
}

Read online:

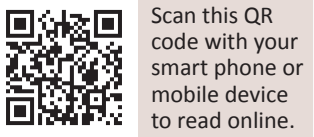

Hendrina Cecilia Kruger's religious mentality profile in her mystical devotional book (c. 1750-1810) from the Trekboer period. The religious views of the Trekboers on the frontier were shaped by pietistic religious literature circulating in the Cape interior. The religious ego-text of Hendrina Cecilia Kruger reflects elements of two streams of pietism: Dutch Second Reformation devotional literature and the works of German pietists in the line of Spener and other German mystics. The cumulative impact of experiential faith in Reformed mysticism and the mystical views of German pietism produced a spirituality of exceptional intensity in the pioneering communities of Reformed believers on the frontier. It is concluded that the mystical religious mentality of the Trekboer pietists exhibited exceptional levels of faith amidst dire physical and emotional conditions on the frontier. In spite of high levels of mystical pietism in her devotional book Kruger remained committed to the basic tenets of Reformed spirituality.

\section{Inleiding}

Die 'Trekboere' was Kaapse veeboere wat in die agttiende eeu om ekonomiese redes en weens droogtes geleidelik oos- en noordooswaarts beweeg het en selfs noord van die Oranjerivier in die Transoranje met hul vee gaan woon en hul mettertyd permanent daar gevestig het, hoewel hulle kerklike en ander bande met die Kaapkolonie behou het (Visagie 2011:8). Tussen 1770 en 1800 het 'n hele aantal groepe soos die Kruger, Steenkamp, Van der Walt en Van Jaarsveld families hulle reeds noord van die Sneeuberge bevind (Spoelstra 1963:19). Vanweë min inwoners in die grensgebiede van Kaapland was ondertrouing by trekboerfamilies in die agttiende eeu'n algemene verskynsel. Gemeenskaplike lotsverbondenheid en familiebande het' $n$ eiesoortige leefwyse onder dié familie-eenhede tot gevolg gehad, wat mettertyd ook 'n eiesoortige geesteskultuur geskep het (Murray 1877). Die opkoms van die piëtistiese ego-kultuur in Europa word deur Mahrholz (1919:143) as 'n versetaksie van die kleinburgerlike bevolking teen marginalisering op kerklike en staatlike terrein, beskryf. Dieselfde sou waarskynlik ook van die kleinburgerlike kultuur onder die trekboerbevolking aan die grense van die Kaapse binneland gesê kon word. ${ }^{1}$ As sodanig kan die piëtisme as sosiale verskynsel as die eerste aanduibare tendens tot die ontwikkeling van 'n 'kleinburgerlike selfbewussyn' beskou word (Mahrholz 1919:143). Die mistieke elemente van die kleinburgerlike piëtistiese leefwyse stel die individu in 'n direkte verhouding tot God met 'n meegaande gevoel van selfbemagtiging (Mahrholz 1919:143). Dié kleinburgerlike godsdienstige weerstand teen hul ontmagtiging maak die mistiek 'n aanloklike geesteshouding (Mahrholz 1919:143). In die Kaapse binneland sou - voortvloeiend uit die piëtisme - dié mistieke gemoedskrag tiperend van die ontwikkelende pionier-etos op die grense word.

Die Kaapse trekboerbeweging het sy hoogtepunt in die loop van die agttiende eeu bereik te midde van 'n Europese sug na godsdienstige vroomheid en die strewe na persoonlike spiritualiteit met sterk mistiek-bevindelike toespitsinge (Ward 2002:1-48). Die gereformeerde godsdiens in Nederland is sedert die einde van die sestiende eeu sterk deur puriteinse denkwyses in Skotland en Engeland beïnvloed, terwyl ortodokse Lutherane in Duitsland die weg voorberei het vir wat Phillip Jacob Spener (1635-1705) later die 'piëtisme' genoem het. Oorkoepelend sou sowel die Nadere Reformasie as die Duitse Piëtisme onder die omvattende benaming van Protestantse Piëtisme tuisgebring kon word. ${ }^{2}$ Andersyds sou vir groter duidelikheid in enger

1.Godsdienstig gesproke was dié versetaksie hoofsaaklik gerig op die formaliteit, rasionalisme en verwêreldliking van die amptelike kerk aan die Kaap. Daarteenoor het die 'kleinburgerlike piëtiste' die klem geplaas op die gevoel, die innerlike geestestoestand van die gelowige en 'n mistieke belewing van die geloof (Schoeman 1995:169)

2.W.J. Op 't Hof (1987:24) se omskrywing van die Protestantse Piëtisme word aanvaar (en toegepas)): ‘[H]et Piëtisme was die stroming binnen het gereformeerde Protestantisme die, zich tegen algemeen verbreide wantoestanden en misvattingen kerned, met profetische

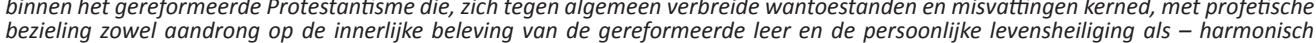
bezieling zowel aandrong op de innerlijke beleving van de gereformeerde leer en de persoonlijke levensheiliging als - harmonisch
hiermee verbonden - ijverde voor de radical heiliging van alle levensgebieden. Anders as die Nederlandse Piëtisme van die Nadere Reformasie het die Duitse mistieke Piëtisme nie die klem op die gereformeerde belydenisskrifte gelê nie, maar op die mistieke eenwording met God. 
verband tussen die Nederlandse gereformeerde piëtisme en die Duitse evangeliese Piëtisme onderskei kon word. ${ }^{3}$

Aan die Kaap is die literatuur van die Nadere Reformasie deur Nederlandse stamouers en besoekende skepe na Tafelbaai gebring waar dit op die voorposte mettertyd die status van 'n uitgebreide godsdienskultuur verwerf het, terwyl Duits-piëtistiese literatuur deur Duitse stamouers na die Kaap gebring, in die aktiewe Lutherse gemeente in Kaapstad gesirkuleer en deur sendingbewuste predikers aan die Kaapse bevolking bekend gestel is. Daar het dit mettertyd die dominante gereformeerde godsdienskultuur binnegedring het (kyk Schoeman 2011:60-63).

Die gemeenskaplike godsdienstige, ekonomiese en sosiale bande van trekboer-familiegroepe in die Kaapse binneland het ' $n$ belangrike rol gespeel om 'n piëtistiese godsdienstige kultuur teskep watinhulontberingsvollebestaankenmerkend van die nomadiese trekboere geword het. Die Krugerfamiliegroep was een van dié wat sterk in die agttiende eeuse trekbeweging na die binneland op die voorgrond getree het. Saam met die families Van der Walt, Steenkamp, Coetzee en Putter het die Kruger-groep reeds in die veertigerjare van die agttiende eeu 'n deel van die emigrasiebeweging gevorm wat oorspronklik noordwaarts beweeg het, na die ooste omgetrek en deur die Karoo tot in die Roggeveld beweeg het (Van der Merwe 1937:2). Op die noordoosgrens van die Kaapkolonie het hierdie trekboere in direkte kontak met vyandelike inheemse stamme gekom, ernstige droogtes beleef en is hulle deur uitmergelende klimaatomstandighede tot relatiewe armoedige lewensomstandighede gedwing.

Die godsdienstige kultuur wat in die geledere van die trekboere ontwikkel het, getuig van 'n vroomheidsreligie wat duidelike trekke van die mistieke bevinding vertoon (Raath 2004:1461-1482). ${ }^{4}$ Die gereformeerde piëtisme wat uit dié godsdiensbeweging na vore gekom het, sou in bepaalde opsigte as 'n godsdienstige 'mentaliteitskultuur' beskryf kon word. Elders is dit reeds ' $n$ 'universaliseerbare' piëtistiese tendens of 'n 'volksreligie' onder die Dopper-trekboerpioniers genoem (Raath 2004:1487). Dié godsdienstige mentaliteitstipe wat 'n eiesoortige gereformeerde religieuse etos tot gevolg had, word deur Spoelstra 'Doppers' genoem (Spoelstra 1963:1, 5, 9, 12-32). Ten spyte van die isolasie van die trekboerpioniers het die preekbundels en stigtelike werke van die sewentiende- en agttiende-eeuse Nederlandse Piëtisme wat saam met die Statenbybel gebruik is, 'n aansienlike mate van godsdienstige vroomheid onder hulle tot gevolg gehad (Schoeman 1995:23).

Die godsdienstige mentaliteit van die trekboerbeweging van die agttiende eeu vertoon die trekke van 'n samehangende geheel van voorstellings, oortuigings, gevoelens, norme en

3.Van 't Spyker (1993:11) verstaan onder Nadere Reformasie "de Nederlandse beweging die samen met het Engelse Puritanisme en het Duitse Piëtisme te beschouwen is als een legitieme voortzetting van het reformatorische kerkelijke en geestelijke ideaal.'

4.Wallmann (2010) beskou die piëtisme as die eng Duitse vorm van dié vroomheidsbeweging wat sedert Spener 'n duidelik afgebakende stroming gevorm het. waardes wat kenmerkend is van 'n spesifieke groep mense in 'n bepaalde tyd en bepaalde milieu - dit wat Frijhoff die godsdienstige mentaliteit van 'n redelik homogene groep noem (Frijhoff 1982:21-44; 1984:406-437). Frijhoff het veral in gedagte die 'vanzelfsprekendheden', wat die ruimte begrens waarbinne idees, emosies en handelinge tot uitdrukking kom (Frijhoff 1982:26). By die godsdienstige mentaliteitstudie van die trekboerlewenswyse handel dit primêr om die kollektiewe geestesgesteldhede wat ten grondslag lê aan die lewe van die mense en familiegroepe wat tussen 1740 en 1800 deel van die trekboerbeweging gevorm het. In dié verband is piëtistiese ego-tekste uit die trekboertydperk belangrike wegwysers by 'n godsdienstige mentaliteitstudie van hierdie piëtistiese vroomheidsbeweging wat mettertyd 'n kenmerkende godsdienskultuur tot gevolg had. Binne hierdie aanwysbare 'godsdienstige mentaliteitsgeskiedenis' van die trekboere was Hendrina Cecilia Kruger 'n tipiese voorbeeld van die mistieke piëtisme in die Suid-Afrikaanse binneland in die tweede helfte van die agttiende eeu.

Die ego-tekskultuur van die ortodokse Lutherane en die Duitse piëtistiesebeweging het dieneerpenvan godsdienstige ego-ervarings bevorder. ${ }^{5}$ In die Suid-Afrikaanse binneland sou eerste- en tweede-geslag-afstammelinge van Duitse stamvaders en -moeders met Nadere Reformasie en Duitspiëtistiese godsdienstige mentaliteitsprofiele waarskynlik toegang tot literatuur uit dié agtergronde in die stamlande hê. Nadere Reformasie-werke soos Florentius Costerus (1656-1703) se De geestelike mensch in sijn begin, voort-gang, en uit-eynde (1687), Jodocus van Lodensteyn (1620-1677) se Beschouwingen van Zion (1674) en Lucretia Wilhelmina van Merken se Het nut der tegenspoeden; brieven en andere gedichten (1762), en uit die kringe van die Luthers-ortodokse voorlopers van die piëtisme: Christian Scriver se Seelenschatz (1675-1692), Gottfried Arnold (1666-1752) se Unparteiische Kirchen- und Ketzer-Historie, von Anfang des Neuen Testaments bisz auf das Jahr Christi, 1688 (twee bande) (1699-1700), sy Historieund BeschreibungderMystischen Theologie/odergeheimen Gottes Gelehrtheit/wie auch derer alten und neuen Mysticorum (1703) en piëtistiese liederebundels van die Evangeliese Broedergemeente het onder die pioniersbevolking in die Kaapse binneland gesirkuleer. In die geval van naverwante van Duitse stamouers met piëtistiese mentaliteitsprofiele was die agttiende eeu verteenwoordigend van die hoogbloei van die Duitse Piëtisme en die herlewing van die Duitse godsdienstige mistiek - evangeliese mistiek met 'n resepsie van mistiek godsdienstige werke soos dié van Johann Tauler (ca. 1300-1361). ${ }^{6}$ Die stamlande van talle vroeë Kaapse families - soos Kruger en Strang (onderskeidelik Duitsland en Noorweë) - het eweneens sterk invloed van Scriver en piëtistiese liederebundels ondergaan. Daarbenewens het leraars soos Jacob Helwig reeds in 1675 by piëtistiese huisbyeenkomste in Stockholm opgetree (Wallmann 2010:37, 268).

\section{Kyk Niggle (1977:3 e.v.) en Mahrholz (1919:204 e.v.).}

6.Wallmann (2010:121): 'Die Blütezeit des Pietismus ist also zugleich eine Blütezeit der Taulerrezeption oder besser der Rezeption der Deutschen Mystik auf dem protestantischen deutschen Büchermarkt. 
Duits-piëtistiese invloed het teen die aanvang van die agttiende eeu ook na die Kaap uitgebrei. In 1706 het lede van die Deense-Halliese sending na die Deense kolonie Trankebar in Indië die Kaap vir die eerste keer besoek, en deur hulle het plaaslike gelowiges met die piëtistiese stromings van Europa kennis gemaak. Hierdie invloed sou versterk word deur die aanwesigheid aan die Kaap dwarsdeur die eeu van ' $n$ beduidende aantal Duitse Lutherane wat in diens van die Kompanjie uitgekom en hul Lutherse bande behou het. Deur die piëtistiese boeke wat hulle uit Duitsland bestel het en deur die dienste wat deur besoekende Lutherse predikante vir hulle gehou is, het daar in die persoonlike vroomheid van die Kaapse bevolking 'n sterk Duits-piëtistiese onderstroming ontstaan wat dwarsdeur die eeu aanwesig was en teen die einde daarvan tot opbloei sou kom (Schoeman 2001:371).

Hendrina Cecilia Kruger se piëtistiese ego-teks is verteenwoordigend van 'n breër piëtistiese 'mentaliteitstroming' onder vroue in Nederland, Duitsland en in die SuidAfrikaanse binneland in die pionierstyd. Eweneens het die gloed van gereformeerde piëtisme in Nederland hoofsaaklik deur Nadere Reformasie literatuur in die loop van die agttiende en negentiende eeu tot die teologiese lewe van die vroue-pioniers in die binneland deurgedring. ${ }^{7}$ Die ego-tekste van Nederlandse vroue soos Maria Bagelaar (1690-1720), Jacoba Petronella Winckelman (1696-1761), Geertje Raaphorst (1700-1776), Eva van der Groe (1704-1770), Geesjen Pamans (1727-1821) en Christina van den Brink $(1747-1817)^{8}$ sou mettertyd parallelle in die handgeskrewe oordenkingsbundels, stigtelike briewe en piëtistiese liederebundels van gereformeerde vroue in die SuidAfrikaanse binneland vind. Pioniersvroue soos Hester Venter, Susanna Smit en Hendrina Cecilia Kruger was verteenwoordigend van 'n soortgelyke godsdienstige mentaliteitstroom wat breed en diep in die gereformeerde denke in die agttiende en negentiende eeu in Suid-Afrika gevloei het. ${ }^{9}$

Andersyds het, benewens die bevindelike godsdienstige belewenis uit die Nadere Reformasie literatuur, die Duitse Piëtisme onder invloed van Spener en die juris Johann Jacob Schütz sowel bruidsmistieke elemente as verenigingsmistieke trekke (in die tradisie van Tauler) in die godsdienstige mentaliteitsprofiel van pionier-ingesetenes aan die Kaap laat opvlam. Piëtistiese liederebundels wat onder Duitse stamverwante aan die Kaap gesirkuleer het, het die piëtistiese mistiek na die binneland help versprei. Die mistieke vereniging met God het veral deur Duitse liederebundels die bestaande gereformeerde godsdienskultuur op die voorposte binnegedring. In die Geistliches neu-vermehrtes Altenburgisches Gesang und Gebeth-Buch van Carl Andreas Redels (1765) wat aan die Kaap in gebruik was, is liedere opgeneem van piëtistiese skrywers soos Johann Arndt (1555-1621), D. Phillip Spener (1635-1705), Heinrich Müller (1631-1675), Valerius

7.Gerstner (1991:76) verkies om nie van piëtisme in Nederland te praat nie, maar van Nadere Reformasie.

8.Kyk Van Lieburg (1991:238-243) vir biografiese gegewens oor hierdie tekste.

9.Vir ego-tekste van hierdie Nederlandse vroue kyk Van Lieburg (1985 en 1991).
Herberger (1562-1627), Johann Heermann (1585-1647) en Johann Gerhard (1582-1637). Die mistieke vereniging met God in Christus kom prominent in talle van hierdie liedere tot uitdrukking. Onder die opskrif 'Von der geistlichen freude' sing Arndt byvoorbeeld van die vreugde oor die nabyheid van Christus:

O Jesu süss! wer dein gedenckt,

dess Hertz mit Freud wird überschwengt:

Noch süsser aber alles ist,

Wo du, o Jesu, selber bist.

(lied 372: vers 1)

Die godsdienstige liedere- en oordenkingsbundel van Hendrina Cecilia Kruger vertoon elemente van sowel die gereformeerde piëtisme uit die Nadere Reformasie as ortodoks-Lutherse en piëtistiese tendense uit die Duitse godsdienstige milieu. Die godsdienstige inslag van die bundel kan getipeer word as piëtisties-misties van aard, met eksplisiete bruismistieke elemente, ekstatiese geloofsbelewenisse en ondertone van asketiese vroomheid.

\section{Die historiese kontekstualisering van Hendrina Cecilia Kruger se oordenkingsbundel Genealogiese agtergrond}

Hendrina Cecilia Kruger is gebore op 24 April 1744 (gedoop 03 Julie 1744). Sy was 'n dogter van Jacob Kruger (of Cruger) (genealogiese verwysing: b1) (gedoop 17 Julie 1718), wat op 25 Oktober 1739 met Christina Strang (gedoop 14 September 1721) in die huwelik getree het. ${ }^{10}$ Hendrina Cecilia Kruger was 'n kleindogter van die stamvader Jacob Kruger van Sadenbeck naby Berlyn, wat in 1713 met die skip 'Middelbank' aan die Kaap gekom het (Mossop 1947:201). Hy is in die Lutherse kerk gedoop. ${ }^{11} \mathrm{Na}$ die verlies van 'n hand verkry hy burgerskap aan die Kaap, waarna hy in die Sandveld boer. Hendrina Cecilia Kruger se grootouers aan moederskant was Carel Strang van Gottenburg en Anna Maria Swart van Stockholm (De Villiers \& Pama 1981:435). Hendrina Cecilia Kruger se stamouers het uit Duitsland en Swede gekom beide lande wat prominent in die ontwikkelende piëtisme van die sewentiende en agttiende eeu gefigureer het.

Hendrina Cecilia Kruger is op 10 April 1763 getroud met Gerrit Steenkamp (gedoop 07 Oktober 1736), 'n seun van Jan Steenkamp van Nieuwkerk en Jannetjie van Eck (Kruger ca. 1750-1810: geslagsregister; De Villiers \& Pama 1981:435). Sover bekend is uit die huwelik van Hendrina Cecilia Kruger en Gerrit Steenkamp agt kinders gebore. Die oudste kind, Johanna, is gebore op 06 April 1764 (gedoop 21 Oktober 1764), en die jongste kind, Carel Gerrit, is gebore op 20 April 1777 (gedoop 31 Augustus 1777) (Kruger ca. 1750-1810: geslagsregister). Twee van haar kinders is by (of kort na)

10.Sy was die dogter van Carel Strang van Gottenburg en Anna Maria Swart van Stockholm.

11.Die stamvader is gebore op 28 Jule. 1690. Sy vader was Frans Kröger, 'n kleinboer, oorlede 1710, en sy moeder Elisabeth Hartwigs, oorlede 1747 (Moritz 1938:234; Mossop 1947:201; Schmidt 1938:86). 
geboorte oorlede: 'n dogter op 20 Desember 1773 en 'n seun op 06 Mei 1776 gebore en agt dae later oorlede (op 14 Mei 1776) (Kruger ca. 1750-1810: geslagsregister) ${ }^{12}$, 'n redelik algemene verskynsel aan die grense.

Gedigte en liedere maak was 'n passie van Hendrina Cecilia Kruger. In haar oordenkingsbundel skryf sy 'n indrukwekkende hoeveelheid godsdienstige verse, waartoe sy op verskillende wyses geïnspireer is. Soms stel sy haar meditasies oor 'n gekose Bybelteks op rym of gee 'n sterfgeval, die vertrek van vriende, ' $n$ aardbewing of moorde aanleiding tot haar digterlike aktiwiteit van piëtistiese verse. Haar gedigte weerspieël ' $n$ begaafde persoonlikheid, opregte vroomheid, toegewyde godsvrug en opvallende mistieke bevinding; 'n sensitiewe gelowige met ' $n$ voorliefde vir asketiese vroomheid.

Die vroeë dood van twee kinders (een beskryf as 'n 'skapie') wat met die Here Jesus verenig word, tref haar swaar. Haar droewige nadenke oor die dood van die kinders bring haar tot die skryf van 'n lang gedig:

Gedigt op de onteijdige dog verhoopende Gotzalig doot van mijn twee jong gebooren kinderkens den eersten ent jaer 1773 den 20 deetzember den tweeden ent jaar 1776 den 6 Mij en den 14 Mij ontslapen. (Kruger ca. 1750-1810: lied 23, vers 4)

Hendrina Cecilia put troos uit die wete dat 'liefste Jezus' sy kinders eenmaal by Hom vergader. (Kruger ca. 1750-1810: lied 23 , vers 15$)$

\section{Sosiale en maatskaplike onstabiliteit op die grense}

Die trekboere wat teen die middel van die agttiende eeu die Bokkeveld ingetrek het, het ook ingesluit individuele jagter en handelaars. Familiegroepe soos die Krugers en Steenkamps het in relatiewe isolasie oor 'n wye gebied in die Bokkeveld en dieper die binneland in gevestig. Jacob Kruger (stamvader) en sy seuns Jacob (genealogiese verwysing: b1), Frans (genealogiese verwysing: b2), Johannes (genealogiese verwysing: b4), Hendrik (genealogiese verwysing: b6) en Pieter Ernst (genealogiese verwysing: b7), met hul gesinne, het hul teen 1750 reeds in relatief geïsoleerde omstandighede in die Bokkeveld en naasliggende gebiede bevind (kyk Mossop 1947:204, 206). Die mate waartoe die trekboerfamilies binne 'n relatief kort tydperk oor 'n groot gebied versprei het, blyk uit die bewegings van Hendrina Cecilia Kruger se vader, Jacob (b1). Hy was aanvanklik 'n knecht in diens van Willem Stolts, 'n boer te Wolvedans en Hoornbosch (Schoeman 2011:331). Later boer Jacob op De Brackekuyl agter Blauwberg aan die Soutrivier, terwyl sy broers vanaf 1748 reeds dieper die binneland in beweeg (Schoeman 2011:331 e.v.). Vanaf 1734 tot 1752 boer Jacob (b1) met skape op De Brackekuyl agter Blauwberg aan die seekant van Kaapstad langs die Mamrepad en noord van die Klein Soutrivier (Mossop 1947:96-97).In 1752 verskuif Jacob Kruger van De Brackekuyl na die Roggeveld sodat hy en sy vier broers teen 1762 aan die grense van die Kaapkolonie gevestig was. In die

12. Hendrina Cecilia Kruger se oordenkingsbundel is ongepagineerd; teenoor liedere verskyn wel nommers. dunbevolkte Roggeveld het die broers en hul nakomelinge herhaaldelik getrou met die families Coetzee, Van Wyk en Steenkamp. Na Jacob (b1) se dood op 10 November 1778 het sy naverwante in die noordwestelike gebiede van die Kaap bly woon (Mossop 1947:97).

Die Kruger-familie het merendeels beskeie geleef, sodat Jacob Kruger (b1), gevestig te 'Tondel Doos Vonteijn', slegs oor 'n perd, 32 beeste en 400 skape beskik het (Schoeman 2011:333). Jaarliks moes Jacob (b1) die moeisame tog vir bywoning van die burgermilisie te Stellenbosch aanpak (Schoeman 2011:333). In sy afwesigheid moes sy vrou, Christina, die boerdery behartig. By geleentheid van Jacob se afwesigheid van die plaas gee sy opdrag aan 'n slaaf om een van die medeslawe, Augustus, vir ongehoorsaamheid te straf. As gevolg van 'n loesing sterf Augustus. Hoewel van owerheidsweë ondersoek na die dood van die slaaf gedoen is, het geen verdere regstappe gevolg nie (Schoeman 2011:333-334).

In die winter van 1783 word Jacob (b1) se seun Jacob (c8) tydens 'n besoek aan die Kaap gearresteer op aanklagte van muntvervalsing en in die tronk aangehou. Later blyk dit dat Jacob (c8) se ouer broer, Carel (c5), vir die vervalsing verantwoordelik was. Jacob (c8) ontsnap uit aanhouding en slaag daarin om na die Bokkeveld te vlug - 'n stap wat hom effektief buite bereik van die gereg in die Kaap plaas (Mossop 1947:214-217). Jacob (c8) en Carel (c5) vestig hul vervolgens dieper die binneland in waar Carel (c5) tydens 'n olifantjag sterf. Jacob (c8) word deur die Britse owerheid van vervolging kwytgeskeld. Jacob (c8) vestig vervolgens in die omstreke van die Kamiesberge in Namakwaland (Schoeman 2011:336).

Die onstabiele en ontberingsvolle omstandighede in die pioniersgemeenskappe op die grense het groot fisieke en geestelike uitdagings aan die pionier-families gestel. Jacob Kruger (c8) se voorkoms het getuig van die ontberings wat die pionierslewe tot gevolg gehad het en die uitdagings wat dit aan die trekboere gestel het. Lichtenstein beskryf hom as 'n persoon van weinig woorde wat selde glimlag; sy oё eerder minagtend jeens gevaar as sprekend van dapperheid; 'n groot grys baard, digte wenkbroue en hare wat oor sy gesig hang gee hom 'n 'wilde en formidabele voorkoms' (Lichtenstein 1930:253). Daarbenewens was hy gewapen met 'n kort, dik olifantroer van vier op die pond - vroeër die eiendom van sy oorlede broer Carel (Schoeman 2011:337).

Teen die sewentigerjare van die agttiende eeu het die seuns van die Krugerstamvader deel gehad aan die trekbeweging vanaf die Roggeveld na die Sneeuberg (Schoeman 2011:337). Dié beweging is egter ernstig gekortwiek deur die beweeglike Boesmangroepe wat strooptogte teen die trekboere van stapel gestuur het (Schoeman 2011:338). Uitgerekte militêre kampanjes en vergeldingsoptrede deur die trekboere was aan die orde van die dag, terwyl die optrede van die Boesmans die lewe vir die trekboere aansienlik bemoeilik het (Schoeman 2011:340). 
'n Verslag van 'n veldwachter rapporteer oor die verliese oor 'n tydperk van twee maande vir die jaar 1779: op 18 Maart is 'n veewagter van Jan Viljoen wreed vermoor en 250 skaap weggevoer; op 08 Maart is 32 melkkoeie van Jasper Smit geroof en 10 geskiet; op 04 April is 150 skaap weggedryf; die 20ste Maart is twee perde van Willem Schalk van Heerden geskiet en 20 stuks vee geneem; op 03 April is 14 beeste van J.J. Swanepoel geroof. Die 12de Mei is vyf beeste van Hendrik van der Merwe geneem, op 13 Maart 20 beeste van Dirk Coetzee en op 29 Maart is sewe kalwers van Jan Andries Esterhuizen geskiet (Moodie 1838:81). Tydens weerwraakaanvalle op die Boesmans het van die trekboere van tyd tot tyd gesneuwel of is later aan hul wonde oorlede. Ockert (van) Schalkwyk was een van diegene wat tydens 'n aanval op die Boemans in die linkerbeen bokant die knie deur 'n pyl gewond is. 'n Deel van die vergiftigde pylpunt het in die wond gebly, as gevolg waarvan Schalkwyk vir nege dae aan die wond gely het en op die plaas van Koekemoer dood en begrawe is (Schoeman 2011:344). ${ }^{13}$

Die dood van Schalkwyk het die klein pioniersgemeenskap diep geraak. Tevergeefs probeer die manskappe die Boesmanaanval afweer. Schalkwyk word getref en ontvang die hulp van sy medeburgers (Kruger ca. 1750-1810: lied 14, vers 7). In gevoelvolle verse beleef Hendrina Cecilia Kruger die dood en lyding van dié mede-trekboer - 'n gedig van drieen-twintig verse met die titel: 'Overdenkenge van het droevege úijt Eijnde Ocker Schalkwijk Tot troost voor zijne bedroefde oúders en Geliefde vrinden. Stemme o Iesraels zieraet'.

Nadat sy die aanvoerder van die burgerkommando verwyt vir allerlei sondes as oorsaak van die ramp wat die kommando getref het, sluit sy met die wete dat die dood voor alle mense se deur staan (Kruger ca. 1750-1810: lied 14, vers 21).

Ten spyte van streng militêre optrede teen die Boesmanaanvallers het die trekboere steeds groot veeverliese gely. Veral die Sneeuberg en omliggende streke het swaar onder die aanvallers deurgeloop. In 1778 het Hendrik Kruger (b6c5) twee honderd skaap verloor en die Khoi-veewagter is noodlottig deur gifpyle gewond. In 1780 is die besittings van Hendrik Kruger (b6) en sy twee seuns verwoes toe die huis waarin dit gestoor is, tydens hul afwesigheid afgebrand is (Schoeman 2011:346).

Benewens georganiseerde Boesmanstrooptogte het insidentele aanvalle deur Khoibendes ook voorgekom. In 1772 het verskeie gevalle van georganiseerde Khoi-geweld op trekboere in die Roggeveld plaasgevind. Die Kruger-familie en naasliggende boeregesinne het die direkte impak van die aanslag ervaar. Die bejaarde Duitser, J.H. Teutman, sy vrou, Jannetjie, en dogter is deur 'n Khoi-bende geskiet, die veewagter van die weduwee Louw vermoor en 575 van haar skaap gebuit. (Moodie 1838:13; Schoeman 2011:351). Met die hulp van twee Khoikapteins is die moordbende in ' $n$ grot vasgekeer, gevange geneem en na die Kaap geneem. Twee

13.Ockert (van) Schalkwyk (b2c1d8) is gedoop op 25 Oktober 1746, oorlede op Koekemoer se plaas 'op Commando', waarskynlik ongetroud. Vir die omvang van militêre konflik op die grense kyk Moodie 1838. van die bende is tereggestel en ander lede van die groep is wisselende vonnisse opgelê (Moodie 1838:17; Schoeman 2011:352; Thunberg 1795/6:185 e.v.\& 263-264). Teutmann se vrou, Jannetjie (gebore Van Eck), is op 19 Mei 1720 getroud met Jan Steenkamp (wewenaar) en na sy dood weer getroud met Johan Heinrich Teutmann te Swartland op 02 April 1747. Jannetjie Teutmann was dus die skoonmoeder van Hendrina Cecilia Kruger.

Die moord op die bejaarde Duitser, sy vrou en dogter, het die trekboere in die omstreke diep geraak. Hendrina Cecilia Kruger het in haar oordenkingsbundel 'n 'Gezang op de doot van mijn Schoon vader en moeder en hare dogter Johan Hendrik Tuijtman oover haare droevege uijt Eijnde. Stemme van de zeeven maagden' neergepen. Die onverwagsheid van die dood van haar skoonouers het die trekboer-gemeenskap in die algemeen en die familie in die besonder waarskynlik swaar getref (Kruger ca. 1750-1810: lied 11, vers 3). Die lyding van die oorledenes moes die trekboergemeenskap besonder droewig gestem het (Kruger ca. 1750-1810: lied 11, vers 5).

Besonderlik swaar vir haar is egter die persoonlike verlies, maar sy berus in die wete dat dit deur God beskik is (Kruger ca. 1750-1810: lied 11, vers 2).

\section{Oor die dood van haar skoonmoeder skryf sy: \\ Ook mijn waerde moeder theder \\ hoe haest wiert úewe oúde leden met droefheijt hier beneden en schrik en angst ter neer gelijt. (Kruger ca. 1750-1810: lied 11, vers 10)}

Hendrina Cecilia Kruger het troos geput uit die kruisdood van Christus en die lyding wat die Heiland onder die toornige hand van God moes deurmaak (Kruger ca. 1750-1810: lied 11, vers 16).

\section{Natuurrampe en kataklismiese gebeurtenisse in die Kaapse binneland}

Natuurrampe en gebeurtenisse wat'n invloed op die trekboere se omstandighede kon hê, het besondere aandag in ego-tekste gekry. In die Nederlands-piëtistiese literatuur is Gods oordele oor land, kerk en volk as eietydse vingerwysings van onverskillige en sondige lewenspraktyke beskou. Florentinus Costerus (1656-1703) se werk Nederlands vloek en zegen en desselfs re-unie ... (1740) was 'n standaardwerk in dié verband.

In 1809 kom 'n aardbewing voor wat die hele Kaapse binneland in beroering had. Nadat die sendeling Mewes Jans Bakker op 04 Desember 1809 'n bidstond oor Psalm 65 vers 12 gehou het oor die dure verpligting om die Evangelie reg te gebruik, by nalate waarvan die toorn van die Here skielik verwek kan word, het ' $n$ aardbewing nog dieselfde aand om tienuur die Kaapse nedersetting getref: 'Ons leedikant schudde met ons heen en weeder en men hoorde een gedruijs, net alsof er veele paarden met waagens door de straat op de hol waaren' (Bakker [1809] 1991:222). Ds. Meent Borcherds het dieselfde gebeurtenis as 'n 'schrik-en ontsteltenis-verwekkend geluid ...' 
beskryf (Borcherds 1830:278 e.v.). In Stellenbosch het die aardbewing mense skrikbevange na die dorpsplein laat vlug (Hugo \& Van der Bijl 1963:152).

Die Sondag na die gebeurtenis (10 Desember) skryf Bakker in sy dagboek dat die opkoms onder die slawe wat hy bedien het 'aanmerkelijk talrijker als langen tijd tevooren' was -'n bewys 'dat die gedugte stem des Heeren (de aardbeving) eenige indrukken veroorsaakt had' (Bakker [1809] 1991:223). Bakker self, sterk tot die piëtisme geneig, kon homself tydens die diens nie bedwing nie en het, meegevoer deur die aandoenlike omstandighede van Gods ingrepe, in trane uitgebars (Bakker [1809] 1991:223-224). ${ }^{14}$

Verder die binneland in is die aardbewing eweneens met skok as 'n vingerwysing van God beskou. Hendrina Cecilia Kruger se oordenkingsbundel bevat 'n lang stigtelike gedig, 'Op de aart beeving op Maandag den 4 Dec. 1809'. Sy beskryf die gebeurtenis as 'n manifestasie van God se almag en 'n teken van oordeel oor die onverskilliges se leefwyse. Teenoor die soewereine mag van God staan die nietigheid van die mens Kruger ca. 1750-1810: lied 47, verse 1 \& 2). Daar is nog tyd om tot inkeer te kom en van die hemeltergende sondes af te sien:

O lants genooten volg myn raet

bekeert ú eer het is te laat ...

(Kruger ca. 1750-1810: lied 47, verse 6 \& 7)

\section{Hendrina Cecilia Kruger se oordenkingsbundel binne die konteks van die gereformeerde en Duitse Piëtisme op die voorposte \\ Die piëtistiese inslag in Hendrina Cecilia Kruger se oordenkingsbundel}

Die piëtisme was 'n godsdienstige beweging wat gedurende die sewentiende eeu onder Protestantse gelowiges van NoordEuropa ontwikkel het in reaksie op wat hulle as formalisme en dogmatisme van die amptelike kerkgenootskappe ervaar het (Wallmann 2010:121). Die piëtisme is 'n faset van 'n komplekse proses van kulturele en godsdienstige interaksie tussen die Protestantse handelsnasies rondom die Noord- en Oossee - Skotland, Engeland, Nederland, Noord-Duitsland, Skandinawië en die Baltiese lande - wat deur skeepsvaarders, koopmanne, studente, reisigers, emigrante en vlugtelinge bevorder is en ook na Noord-Amerika oorgedra is (Schoeman 1997:124). Die gereformeerde piëtisme het in die loop van die sewentiende en agttiende eeu veral in die Engelse godsdiensmilieu (onder Puriteine), in Nederland (die Nadere Reformasie) en Duitsland (die piëtisme in enger sin) gebloei. Binne bestaande kerke en gereformeerde oortuigings het piëtistiese geneigdhede lidmate wat oor hul sieleheil besorg was, vir wedersydse stigting en bemoediging

14.Die aardbewing het 'n sterk godsdienstige effek op Bakker se voortgaand bediening gehad: 'Ja, eenige konden mij daarna betuijgen dat de aardbeeving het middel was geweest om hun niet alleen tot de Heere uijt te drijven maar om tot ruijmte te koomest on hus tot de verzeekerd heijd van te drijven, maar om tot ruljute te koeweest om hun niet alleen tot de Heere uijte driven, maar om son Chistus en alle Zijne beloften; en dat wel eeen mij konde betuijgen dat die sooveel van de liefde Gods in 't hart gevoelde, somtijds sooveel als die maar konde draagen, en er onder soude moeten beswijken wanneer dit hooger ging; dus kran van liefde' (Bakker [1809] 1991:224). 'bymekaar gebring' om naas leersuiwerheid ook aandag aan lewensheiliging en vroomheid te skenk, met daarby 'n uitgesproke neiging tot die mistiek (Schoeman 1997:124; Graafland 1983:1-19). In Duitsland het Philipp Jacob Spener (1635-1705) as grondlegger van dié beweging in bepaalde opsigte die voortou geneem. Spener se heruitgawe van die Theologia Deutsch, preke van Johann Tauler, Thomas à Kempis se Navolging van Christus en Johann Arndt se tekste het tot ' $n$ mistieke opbloei onder ortodokse Lutherane gelei. In sy Pia desideria (1675) het Spener die oogmerke van die mistieke piëtisme verwoord (Wallmann 2010:118).

Teen die middel van die agttiende eeu het die gereformeerde piëtisme in Nederland dermate gebloei dat werke van outeurs uit die kaders van die Nadere Reformasie in tienen honderdtalle op die teologiese boekemark verskyn het. Nederlandse gereformeerde piëtiste soos F. Ridderus (1620-1683), G. Saldenus (1627-1694), S. Oomius (16281706), G. Voetius (1589-1676), H. Witsius (1636-1708) en J. Hoornbeeck (1617-1666) is sowel in Nederland as aan die Kaap wyd gelees. ${ }^{15}$ Die mees populêre stigtelike piëtistiese werke in hierdie kaders was dié van Willem Sluiter (1627-1673), W. à Brakel (1635-1711) en Bernardus Smytegeld (1665-1739), ${ }^{16}$ terwyl Duits-piëtistiese liederebundels en oordenkingstof onder Duitse families gewild was. Aan die Kaap is benewens J.A. Bengel se werk oor die Bybelboek Openbaring (Erklärte Offenbarung Johannis oder vielmehr Jesu Christi ... [1746]) ook diverse piëtistiese liederebundels gebruik.

In die stigtelike literatuur van die Nadere Reformasie was sterk Middeleeuse spore van die mistiek te vind. W.J. Op 't Hof spoor selfs die voedingsbodem van die Nederlandse Piëtisme tot die Middeleeuse devosie en mistiek na (Op ' $t$ Hof 1987:598-600). Soos Nadere Reformasieliteratuur het Duits-piëtistiese werke nie 'n gebrek aan mistieke gloed vertoon nie.

Hoewel die hele Kaapse gebied in die loop van die agttiende eeu sterk invloede van die gereformeerde piëtisme verraai het, was dit veral die trekboerfamilies op die voorposte wat diepgaande piëtistiese invloede van sowel gereformeerde as Spenerse mistiek vertoon. Trekboerpioniers in die binneland het in bepaalde gevalle invloed van beide piëtistiese kulture weerspieël: 'n groter mate van Christus-gesentreerde

15.Veral Franciscus Ridderus se Schriftuurlijk bewijs voor den heiligen doop van naastgeloovige ouders kinderen ... (1673), Oomius: Het geopende en wederleyde naastgeloovige ouders kinderen ... (1673), Oomius: Het geopende en wederleyde
Muhammedisdom of Turckdom ... (1663); Schrifteurlijke prognosticatie, ofte, Muhammedisdom of Turckdom ... (1663); Schrifteurlijke prognosticatie, ofte,
voor-beduydtselen van Godts naerderende oordeelen over landen en luyden den ingesetenen der Vereenigde Nederlanden ... (1666); Voetius: Catechisatie over den catechismus der Remonstranten, tot naerder openinghe ende oeffeninghe voor hare catechumenen (1641); Witsius: Oefeningen over de grondstukken van het algemyne Christelijke geloove, en het gebed des Heeren ... (1700), Twist des Heeren met sijn wyngaerdt de selve over tuygende van misbruyck sijner weldaden, (1692), Vier boeken van de verscheyden bedoelinge der verbonden Gods met de Menschen (1696); Hoornbeeck: Belydenis predicatie over 1 Tim iii:15 (1648).

16.Van Sluiter: Buyten-eensaem huys, somer en winter-leven, aenwijsende, hoe men op een slechte en eensaeme plaets, buyten op 't land vergenoegd mag leven, meer dan in 't gewoel van groote en aansienlijke steeden (1680); A Brakel: meer dan in 't gewoel van groote. Logiké Latreia, dat is redelyke godtsdienst, in wek smyeden des predikatien vgs handschrift van 1698 tot $1713(1713)$, Des Christens heil en cieraat, voorgestelt in vyf-en-veertig predicatien ... (1740), Een woord op syn tyd, of tweeen-veertig predicatien naar tydsomstandigheden geschikt ... (1745). 
bruidsmistiek, ekstatiese geloofsbelewenisse en 'n asketiese vroomheidsgeneigdheid.

\section{'n Geneigdheid tot Christosentriese bruids- en verenigingsmistiek}

Die opbloei van die Christelike mistiek tydens die Middeleeue het veral gepaard gegaan met'n sterk neiging tot bruidsmistieke geloofservarings. Die mistieke toegang tot God deur 'n studie van die Woord en toegewyde bepeinsing manifesteer reeds in die godsdienstige denke van Origines van Alexandrië (ca. 185-c 254). Ambrosius van Milaan (ca. 340-397) het die mistiek 'n blywende deel van die Christelike geloofstradisie gemaak (Raath 2011:2). Hoewel die filosofiese mistiek van die Duitsers Meister Eckhart en Johann Tauler (ca. 1300-1361) 'n groot invloed op die vroeë piëtisme uitgeoefen het, was dit Origines en Bernard van Clairvaux (1090-1153) sebruidsmistiek wat die gereformeerde piëtisme rigtinggewend beïnvloed het (Raath 2011:2). Die ekstatiese Belewing van die vereniging met God vind plaas wanneer die menslike persoonlikheid in die Ewige versink. Vergesel van die idee dat vereniging met God bewerkstellig word deur asketiese nadenke oor menslike onwaardigheid en die verlossingswerk van God, het bruidsmistieke meditasie en emosionele hunkering na die vereniging met God 'n onderskeibare tendens van die piëtistiese geloofsbelewenis gevorm. Dié tendense is versterk deur die terugval van gereformeerde piëtiste op Middeleeuse mistici soos Bernard van Clairvaux (1090-1153), Jean Charlier Gerson (1363-1429) en Johann Tauler se werke (Op 't Hof 1991:73-120). Theodorus à Brakel (1608-1669), een van die vernaamste bronne van gereformeerde mistiek op die Kaapse voorposte, se werk is geheel deurdrenk van die Bernardynse mistiek ${ }^{17}$. Bernardus, die laaste van die kerkvaders, was binne die Nadere Reformasie die mees geliefde Rooms-Katolieke outeur. Jodocus van Lodensteyn (1620-1677) - ewe geliefd as À Brakel op die voorposte - het die verval van die RoomsKatolieke Kerk eers met die dertiende eeu, dus ná Bernardus, nagespoor (Op ‘t Hof 1991:106). Dít was 'n tendens wat reeds by reformatore soos Luther en Calvyn voorgekom het. Van gereformeerde piëtiste se voorkeure skryf Op ‘ $t$ Hof (1991):

$\mathrm{Na}$ het kerkvaderschap was het de gevoelige en liefdelijke bruidsmistiek die in Bernardus de nadere reformatore sterk aansprak en aantrok. Bij hem vernamen zij de tale Kanaäns en ademden zij een bevindelijkheid waarbij hun harten openbloeiden. (bl. 107)

Die gereformeerde piëtisme in Nederland sowel as in die Kaapse binneland het eweneens die invloed van bruidsmistieke belewenis en asketiese geneigdheid vertoon. In Johannes Groenewegen (1710 - ca. 1755) se populêre mistieke liederebundel De Lòfzangen Israels, waar onder de Heere woont. Zijnde eenige geestelijke liederen skryf hy oor 'het verkwiklijk eenzaam':

Dat eenzaam zyn is my zoo goed;

Daar mijn gemoed /

Het hoogste goed /

Geniet / die ware rust ...

([1782] 1841: I:50, Lied 18)

17. Het geestelijke leven ende de stant eens geloovigen mensches hier op a arden ... (1649) De trappen des geestelyken levens beschreven door Theodorum à Brakel ... (1680).
Benewens die motief van eensaamheid, kom bruidsmistieke beskrywings gebaseer op Hooglied ook in Groenewegen se liedboek voor: 'n 'Lofzang op het Geestelijke Huwelyk' en liedere gebaseer op Hooglied $(5: 16 ; 1: 4 ; 4: 9$ en $4: 16)$ (Groenewegen [1782] 1841:41 e.v., 108, 118, 162 en 137), terwyl J. van Lodensteyn (1620-1677) ook getrag het om 'Het Onverloochende, Doode, en Geesteloose Christendom' met predikasies oor Hooglied 5:3, 5:8 en 1:4 tot nuwe lewe in Christus te inspireer (Van Lodensteyn 1732:206 e.v., 227 e.v.).

Die eensaamheid in die afgeleë dele van die Kaapse binneland sou daartoe meewerk dat die geestelike ervaring van Christus se liefde en die hunkering na die nabyheid van die Verlosser met ' $n$ opregte gevoel en mistieke ervaring in Hendrina Cecilia Kruger se oordenkingsbundel tot uiting kom. Sy skryf 'n gedig in dertien verse met besondere klem op die bruidsmetafore in Hooglied: 'Úijt het hooge liet Zalomons kantika 5 vers 2 den geestelikken bruijt met haren brúijdegom Jezus. Stem ons Schepzel die gaan al van de ree.' Jesus verskyn onverwags voor die deur van haar hart (Kruger ca. 1750-1810: lied 13, vers 1).

Die res van die gedig is oorwegend ' $n$ dialoog tussen Jesus (Bruidegom) en haarself (bruid). Die inslag van die gedig is oorwegend minnebeskrywings met mistieke ondertone (Kruger ca. 1750-1810: lied 13, vers verse 7 \& 8). Die mistieke ontmoeting eindig met die wete dat die dood nie die liefde tussen Bruidegom en bruid ongedaan maak nie (Kruger ca. 1750-1810: lied 13, vers 13).

\section{Ekstatiese geloofsbelewenisse}

Die Middeleeuse Bonaventura (1217-1274) vertoon reeds in die dertiende eeu 'n kombinasie van bruidsmistiek, ekstatiese geloofsbelewenisse en asketiese geneigdheid in sy teologiese opvattings (Bonaventura 1978:173). Bonaventura beskryf die vereniging van Christus met die gelowiges as 'n geestelike bruilof (Bonaventura 1978:168).

Volgens Wallmann (2010:105) is die bruidsmistiek deur Luther en die Lutherse ortodoksie vir die Protestantse teologie gelegitimeer. Johann Arndt se Von der Vereinigung der Gläubigen mit ihrem Haupt Jesus Christus het die bruidsmistiek in die ortodokse Lutherse teologie ' $n$ blywende gestalte gegee (Wallmann 2010:110).

In die Nederlandse gereformeerde Piëtisme loop bruidsmistieke ervarings hand aan hand met meer of minder intensiewe geestesberoeringe. Uitstorting van ego-ervarings en ekstatiese geloofswendinge is kenmerkend van egotekste uit die piëtistiese geloofwêreld van Nederlandse gereformeerdes. Dieselfde geneigdhede is ook in piëtistiese egobeskrywings in die Suid-Afrikaanse binneland te vinde. Sowel gereformeerde pioniersvroue as -mans het spore van sodanige geneigdhede vertoon (Raath 2011:1-9). In Hendrina CeciliaKruger se oordenkingsbundel is veranderende sielsen gemoedsgestaltes vanweë intense geloofservarings nie vreemde verskynsels nie. In haar 'Eerste Gezang mjner ziels 
veranderenge. Stemme mijn schoone kloorezi' gee sy 'n uitvoerige beskrywing van ' $n$ visioen - 'n sielsveranderende ervaring wat sy in haar jeug gehad het. Terwyl sy op haar bed gerus het, is sy uit haar slaap gewek, waarna sy in 'n visioen twee 'geeste' wedervaar: een soos kristal, wit soos wol en deur lig omgewe; die ander 'zeer schrikkelik' - skynbaar die Satan: 'het scheijnt den Zatan en zijn gedugte afgrijzelik' - 'n gesig wat haar bevrees gelaat het (Kruger ca. 1750-1810: lied 2, vers 6).

Haar familielede het geweier om te glo dat die verskynsels wat sy wedervaar het, werklik was. Haar moeder se ongeloof oor die verskynsels het Hendrina Cecilia Kruger soos volg verwoord:

$$
\begin{aligned}
& \text { Dit ging ik als dan verhaalen } \\
& \text { aen mijn mama } \\
& \text { maer het werd als eijdel thaalen } \\
& \text { van haer verstaa } \\
& \text { (Kruger ca. 1750-1810: lied 2, vers 8) }
\end{aligned}
$$

Daarna het sy weer twee keer soortgelyke visioene wedervaar: die eerste keer het sy haar suster daarop attent gemaak; die tweede keer het sy ' $n$ helder lig bemerk wat aan haar verskyn het. Die gemoedsveranderinge wat sy ondergaan het, het sy in digvorm beskryf as 'Het tweede gezang mijner ziels veranderinge genade werk. Een gebrooken ende verslagen herte en zúlt gij o Got niet veragten. Stemme 100` (Kruger ca. 1750-1810: lied 3, verse 1-22). Die inhoud daarvan is oorwegend ' $n$ opregte ervaring van haar eie sondigheid en skuld voor God (Kruger ca. 1750-1810: vers 8).

\section{Geneigdheid tot asketiese vroomheid}

Thomas à Kempis (ca. 1380-1471) se Navolging van Christus lê sterk klem op afsondering en oorpeinsing as prysenswaardige deugde. À Kempis se mistieke uitsprake in sy Navolging het 'n sterk invloed op vroeë Reformatoriese werke uitgeoefen. Ander werke van hom wat in Nederlands verskyn het, Eenige tractatjens, Het hofken der roosen en Het dal der lelien (1680), het eweneens 'n rigtinggewende rol gespeel om mistieke askese 'n prominente kenmerk van die gereformeerde piëtisme te maak (kyk Raath 2004:1449-1489). Thomas à Kempis se impak op die gereformeerde Piëtisme was nie veel minder as dié van Bernard nie. Die invloedryke gereformeerde piëtis Teellinck het byvoorbeeld in die eerste deel van sy Sleutel der devotie: Ons geopenende de deure des hemels (1624) reeds 'n groot gedeelte van die vierde boek van À Kempis se De imitatione Christi verwerk. Op 't Hof bevind dat hy ook die sesde boek van die tweede deel van die genoemde geskrif (1656) vir 'n groot gedeelte ontleen het aan die tweede en derde boek van À Kempis se hoofwerk (1990:88-112; 1991:1-13). Benewens die Bernardynse mistiek het À Kempis die gereformeerde piëtisme in ander opsigte rigtinggewend bevrug. Met sy eenvoudige, skriftuurlike en pakkende styl het À Kempis die selfverloëning gestimuleer, die hegte verbondenheid met die Here Jesus beklemtoon en die verlange en strewe na geestelike en hemelse sake by gelowiges aangewakker (Op 't Hof 1991:1-13). Veral die motief van eensaamheid en afsondering sou die gereformeerde pioniers op die voorposte met 'n sterk geneigdheid tot introspeksie en oorpeinsing aanspreek.
By Hendrina Cecilia Kruger kom trekke van wat genoem kan word 'vroomheidsaskese' na vore - die hunkering na asketiese afsondering ter wille van meerdere vroomheid. Die afsondering met Jesus is die hoogste goed:

Verkeer ik in het eenzaam met Jezus gemeenzaam dan wens ik niets meer en rijs ik met anderen wij troosten malanderen en looven den Heer (Kruger ca. 1750-1810: lied 53, vers 8)

Vermyding van die wêreld, opvattings oor die 'vyandige wêreld' en 'verval' in die wêreld had 'n 'ontwykings-' of 'vermydingsvroomheid' tot gevolg wat ook in Hendrina Cecilia Kruger se oordenkingsbundel 'n sterk inslag handhaaf (bv. Kruger ca. 1750-1810: lied 49, verse 1-7).

\section{Slot}

Lucinda Martin (2010:400) merk op dat dit grootliks onbekend is hoeveel vroue in Europa in die algemeen en Duitsland in besonder aktief aan die piëtistiese beweging deelgeneem het. Aanduidings bestaan dat die getal groter is as wat vermoed word. Aansienlike getalle vroulike korrespondente met Francke en Spener dui daarop dat die rol van vroue in die piëtisme meer beduidend was as wat tot dusver aanvaar is. In sy biografie bedank die piëtis Johann Wilhelm Petersen byvoorbeeld die groot getal mense wat hom sedert sy ampsontheffing ondersteun het - waaronder 'n beduidende aantal vroue. In sy Gynaecum Haeretico Fanaticum skryf Johann Feustking selfs dat die piëtisme in Duitsland deur vroue gevestig en uitgebrei is (Martin 2010:387). ${ }^{18}$

Die frekwensie van vroulike piëtiste ego-tekste in die Kaapse pionierslewe van die agttiende en negentiende eeu dui eweneens op grootskaalse meelewing en beïnvloeding deur die piëtisme. Hendrina Cecilia Kruger was slegs een van 'n hele aantal vroue-piëtiste wat op die voorposte hoër vlakke van spirituele intensiteit weerspieël het. Beduidende vlakke van mistieke ekstase, bruidsmistieke ervarings en piëtistiese ego-belewenisse skyn méér dikwels onder vroulike as onder manlike pioniers voor te kom.

Hoewel Feustking se opmerkings hierbo waarskynlik om anti-feministiese redes neergepen is, dui die inhoud daarvan op 'n beduidende piëtistiese betrokkenheid onder vroue. Die eensaamheid, afsondering en ontberingsvolle omstandighede waaronder trekboer-vroue aan die grense van die Suid-Afrikaanse binneland blootgestel was, sou daartoe meewerk om ' $n$ godsdienstige mentaliteitstipe te skep wat uit sowel die Nederlandse gereformeerde Piëtisme as dié van Spener geput het, hul lewensuitdagings aan die hand daarvan getrotseer het en godsdienstig hoë vlakke van geloofsintensiteit weerspieël het. Onder troostelose omstandighede sou die intense ervarings van bruidsmistieke aard, visionêre opwellings en asketiese vroomheid 'n godsdienstige estetika tot gevolg gehad het wat hul dikwels in die harde werklikheid van die pioniersbestaan moes ontbeer.

18.Verwysend na die heilige Katharina van Genua en Jeanne-Marie de Guyon (1648-1717) - beide invloedryke persone in die Franse Quietisme. 
Sowel die gereformeerde as die evangeliese piëtisme is verteenwoordigend van 'n spontane opwelling teen die rasionalistiese spiritualiteit en meegaande beklemtoning van die menslike vermoëns in die teologie van die sewentiende en agttiende eeu. Ten spyte van opvallende verskille tussen dié twee vorme van piëtisme is daar wel duidelike punte van ooreenstemming te bespeur: die klem op die diepgang van die geloofslewe, die bevindelike kennis van die heil, die waaragtigheid en werklikheid van die lewensverbinding met die lewende Christus en die werk van die Heilige Gees in die Godsopenbaring.

Die bevindelike in die piëtisme was 'n pleidooi vir die aanvaarding van God se openbaring in die lewenspraktyk van die gelowige. By piëtistiese gelowiges soos Hendrina Cecilia Kruger is die allereerste vraag nie of wat hulle glo en bely waar is nie, maar of hulle die lewende God in sy Woord ontmoet en die lewewekkende Woord uit sy mond verneem. Die werklikheid van die mistieke omgang met God in Christus is by Hendrina Cecilia Kruger geen beeldspraak dat die lewende Heiland haar troos met sy liefde en nabyheid, ja, haar in sy arms hou en vertroos en bemoedig nie. Vir haar is dit alles waaragtig en werklik omdat Christus die Lewende is en Hy deur die Heilige Gees Homself so aan sy bemindes openbaar, alle twyfel uit die harte van die gelowiges wegneem en sy verlossingswerk in alle omstandighede van die lewe werklik is. Die mistieke omgang met God transendeer die rasionale aanvaarding van die Woord; dit fokus die geloof op Christus se selfopenbaring as 'n waaragtige lewensverband met Christus die Lewende. Sowel die mistieke as die bevindelike piëtisme van Hendrina Cecilia Kruger plaas haar volledig binne die kaders van die gereformeerde en die evangeliese piëtistiese strominge van haar tyd.

Die piëtistiese klem op die mistieke weg het in die agttiende eeu by sommige gelowiges gevaarlike uitlopers ontwikkel: Christus se openbaring is met allerlei bonatuurlike verskynsels in verband gestel, aan die hand van seldsame gemoedsbewegings verklaar en van die hoofsaak van die geloof afgetrek. Die gevaar om Christus se openbaringswerk in allerlei bykomstighede en hartstogtelike ervarings te soek was immer teenwoordig. Die klem op die bykomstige mag daartoe lei dat die openbaring van Christus deur die krag van die Heilige Gees in die Woord verduister word.

Waar lê die spirituele fokus in die Kruger-ego-teks? Die ware geloof word nie bepaal vanuit die mens met sy verskillende funksies en sielswerksaamhede nie, maar vanuit die openbaring van God in die evangelie van Jesus Christus. In dié evangelie kom God in Christus tot haar en maak haar sy genade deelagtig. Die lewende geloof in Christus lei haar op die mistieke weg: haar ontlediging van haarself en haar eie werke; die verligting deur die Gees en haar ekstatiese toeëiening van die genade in Christus is 'n werklike en onverbreeklike band. Haar bevindelike geloofservarings bly steeds gerig op die geloof, die oortuigende werk van die Heilige Gees, waardeur sy van die bande van sonde losgemaak en verbind word aan Jesus Christus.
Die samevloeiing van die bevindelike in die geformeerde piëtisme en die mistiek van die Duitse Piëtisme het 'n spiritualiteit van uitsonderlike intensiteit onder die pioniersbevolking van die Kaapse grensbewoners tot gevolg gehad; 'n godsdienstige mentaliteitsprofiel gekultiveer wat onder uiterste fisieke en emosionele omstandighede die krag van Christus se nabyheid in hul lief en leed ervaar en besondere hoë vlakke van geloofskrag in die lewensomstandighede van die pioniersbevolking ontlaai het. By Hendrina Cecilia Kruger word die bevinding nie losgemaak van die geloof en die Woord nie. Haar ego-teks plaas nie die geloof, bevinding of mistieke belewing in die sentrum nie, maar die evangelie van Jesus Christus en sy werk in haar lewe. As sodanig sluit Hendrina Cecilia Kruger se ego-teks aan by die mistieke en bevindelike kultuur van die Reformasie - wesenlike en konstitutiewe elemente van die lewende geloof. Hendrina Cecilia Kruger se bevindelike mistiek is as sodanig nie 'n reaksie teen nie, maar 'n aktualisering van die gereformeerde godsdiens met die klem op die volstrekte soewereiniteit van God. Waarheid transendeer die rasionele; waarheid is méér en iets anders as ' $n$ lys van verstandelike leerstellings wat as waar aanvaar moet word: waarheid is Begegnung.

Die bevindelike mistiek in die Kruger-ego-teks bevat ook 'n belangrike aanwysing vir gelowiges dat die geloofsversorging van die gereformeerde belyder wat erns met die evangelie maak, nie slegs tot die prediking beperk is nie. In die mistieke bevinding van die geloofslewe word grense aan die kerklike prediking gestel. Die Kruger-egoteks herinner daaraan dat daar méér van God in die wêreld is as slegs die prediking. Daar is ook die werk van die Gees in die hart van die gelowige - 'n 'verlengstuk' van die Woord; dít waarin die Woord penetreer en resoneer tot in die kern van die menslike eksistensie. In die Kruger-ego-teks word gelowiges gewys op die waaragtige werking van die inhabitation Spiritus Sancti - in werklikheid die inhabitation trinitatis, die genadige inwoning van die Godheid in die mens - 'n waarheid reeds in die agttiende eeu deur sowel Nederlandse as Duitse piëtiste ingesien.

\section{Erkenning Mededingende belange}

Die outeur verklaar dat hy geen finansiële of persoonlike verbintenis het met enige party wat hom nadelig kon beïnvloed in die skryf van hierdie artikel.

\section{Literatuurverwysings}

Bakker, M.J., [1809] 1991, Dagboek en brieven van Mewes Jans Bakker (1764-1824), Een Friese zendeling aan die zuidpunt van Afrika, (Geredigeer deur Huusen, A.H. \& Veltkamp-Visser, S.B.I.), Suid-Afrikaanse Instituut, Amsterdam.

Bengel, J.A., 1746, Erklärte Offenbarung Johannis oder vielmehr Jesu Christi. Aus dem revidirten Grund-Text übersetzet: Durch die prophetische Zahlen ausgeschlossen: Und Alle, die auf das Werk und Wort des HERRN achten, und dem, was vor de Thür ist, würdiglich entgege zu kommen begehren, zweite Auflage, Verlegts
Johann Christoph Erhardt, Stuttgardt.

Bonaventura, 1978, The soul's journey into God; the tree of life; the life of St. Francis, transl. E. Cousins, Paulist Press, Mahwa, NJ.

Borcherds, M., 1830, 'Beschrijving van Stellenbosch', NZAT, 278-283.

Costerus, F., 1740, Nederlands vloek en zegen en desselfs re-unie, Reinier en Adrianus Brouwer, Hoorn. 
De Villiers, C.C. \& Pama, C., 1981, Geslagsregisters van die ou Kaapse families, DI. 1: A-M, A.A. Balkema, Kaapstad/Rotterdam.

Frijhoff, W.Th.M., 1982, 'The French connection: Mentaliteitsgeschiedenis als cultuurstrijd', in D. Monica et al. (red.), Geschiedenis, psychologie, mentaliteit: negen discussiebijdragen, bl. 21-44, Uitgeverij Skript, Amsterdam.

Frijhoff, W.Th.M., 1984, 'Impasses en beloften van de mentaliteitsgeschiedenis', Tijdschrift voor sociale geschiedenis 10, 406-437.

Gerstner, J.N., 1991, The thousand generation covenant. Dutch Reformed covenant theology and group identity in colonial South Africa, 1652-1814, E.J. Brill, Leiden/ New York, NY.

Graafland, C., 1983, 'De invloed van het puritanisme op het onstaan van het Gereformeerd piëtisme in Nederland', Documentatieblad Nadere Reformatie 7(1), 1-17.

Groenewegen, J., [1742] 1841, De lofzangen Israels, waar onder de Heere woont. Zijnde eenige geestelijke liederen, DI. I \& II, J. van Golverdinge, 'S Gravenhage.

Hugo, A.M. \& Van der Bijl, J., 1963, Die kerk van Stellenbosch, 1686-1963, TafelbergUitgewers, Kaapstad.

Kruger, H.C., ca. 1750-1810, 'Liedboek en oordenkingsbundel', ongepubliseerde manuskrip. (Kopie in die versameling van A.W.G. Raath).

Lichtenstein, H., [1815] 1930, Travels in Southern Africa in the years 1803, 1804, 1805 and 1806, DI. 2, Herdruk van die vertaling uit Duits deur Anne Plumtre, Van Riebeeck Vereniging, Kaapstad.

Mahrholz, W., 1919, Deutsche selbstkenntnisse. Ein Beitrag zur Geschichte der Selbstbiographie von der Mystik bis zum Pietismus, Furche-Verlag, Berlyn.

Martin, L., 2010, 'Öffentlichkeit und Anonymität von Frauen in (Radikalen) Pietismus Die Spendentätigkeit adlicher Patroninnen', in W. Breul, M. Meier \& L. Voge (Hrsg.), Der radikale Pietismus. Perspektiven der Forschung, bl. 384-400, Van den Hoek \& Ruprecht, Göttingen.

Moodie, D., 1838, The record; or, a series of official papers relative to the condition and treatment of the native tribes of South Africa, part III. 1769-1795, A.S. Robertson, Kaapstad.

Moritz, E., 1938, Die Deutschen am Kap unter der höllandischen Herrschaft 1652-1806, Verlag Hermann Böhlaus, Weimar.

Mossop, E.E., 1947, Lives of the earlier Krugers told in a revised genealogical table. Archives Year Book for South African History, Government Printer, Kaapstad.

Murray, J., 1877, 'Some characteristics of our fellow colonists', in Cape Monthly Magazine.

Niggle, G., 1977, Geschichte der deutschen Autobiographie im 18. Jahrhundert. Theoretische Grundlegung und literarische Entfaltung, J.B. Metzler, Stuttgart.

Op 't Hof, W.J., 1987, Engelse piëtistiese geschriften in het Nederlands, 1589-1622, Lindenberg, Rotterdam.

Op 't Hof, W.J., 1990, 'Thomas à Kempis bij Willem Teellinck (2)', Documentatieblad Nadere Reformatie 14(2), 88-112.

Op 't Hof, W.J., 1991, 'Thomas à Kempis bij Willem Teellinck (3)', Documentatieblad Nadere Reformatie 15(1), 73-120.
Raath, A.W.G., 2004, 'Bevinding en geestelike verlating op die limiete: Die historiese en teologiese kontekstualisering van die pioniersvrou Hester Venter (ca. 17501830) se Ondervindelijke Bekeeringsweg', HTS Teologiese Studies/Theological 1830) se Ondervindelijke Bekeeringsweg', HTS Teologiese Studies/
Studies 60(4), 1449-1489. http://dx.doi.org/10.4102/hts.v60i4.632

Raath, A.W.G., 2011, 'Gereformeerde mistiek en die neerslag daarvan in die piëtistiese ego-tekste van manlike gelowiges in die Suid-Afrikaanse pionierslewe', HTS Teologiese Studies/Theological Studies 68(1), 1-9. http://dx.doi.org/10.4102/hts. v68i1.1123

Redels, C.A., 1765, Geistliches neu-vermehrtes Altenburgiches Gesang- und GebethBuch, in sich haltend den kern Alten und Neuer geistreichen Lieder und Gesänge D. Martin Luthers und andere christlicher Lehrer und frommer Christen, Paul Emanuel Richtern, Altenburg.

Schmidt, W., 1938, Der Kultur-anteil des Deutschtums am Aufbau des Burenvolkes, Hahnsche Verlagsbuchhandlung, Hannover.

Schoeman, K., 1995, Die wêreld van Susanna Smit 1799-1863, Human \& Rousseau, Kaapstad/Johannesburg/Pretoria.

Schoeman, K., 1997, Dogter van Sion. Machtelt Smit en die 18de-eeuse samelewing aan die Kaap, 1749-1799, Human \& Rousseau, Kaapstad/Pretoria/Johannesburg.

Schoeman, K., 2001, Armosyn van die Kaap. Die wêreld van 'n slavin, 1652-1733, Human \& Rousseau, Kaapstad/Pretoria/Johannesburg.

Schoeman, K., 2011, Cape lives of the eighteenth century, Protea Book House, Pretoria.

Spoelstra, B., 1963, Die 'Doppers' in Suid-Afrika 1760-1899, Nasionale Boekhandel, Kaapstad.

Thunberg, C.P., 1795/6, Travels in Europe, Africa, and Asia. Performed between the years 1770 and 1779, DI. 1, W Richardson, Cornhill \& J Egerton, Londen.

Van der Merwe, P.J., 1937, Die noordwaartse beweging van die boere voor die Groot Trek (1770-1842), W.P. van Stockum \& Zoon, Den Haag.

Van Lieburg, F.A., 1985, 'Vrouwen uit het gereformeerde pietisme in Nederland (2); Jacoba Petronella Winckelman (1696-1761)', Documentatieblad Nadere Reformatie IX(4), 119-127.

Van Lieburg, F.A., 1991, Levens van vromen. Gereformeerd pietisme in de achttiende eeuw, De Groot Goudriaan, Kampen.

Van Lodensteyn, J., 1732, Geestelyke opwekker, voor het onverloochende, doode, en geesteloose Christendom voorgestelt in X. Predicatien, 3e druk, Adrianus \& Johannes Douci, Amsterdam.

Van 't Spyker, W., 1993, 'Orthodoxie en Nadere Reformatie', in T. Brienen, K. Exalto, C. Graafland, B. Loonstra \& W. Van 't Spyker (reds.), Theologische aspecten van de Nadere Reformatie, bl. 11-27, Uitgeverij Boekencentrum, Zoetermeer

Visagie, J.C., 2011, Voortrekkerstamouers 1835-1845, Protea Boekhuis, Pretoria.

Wallmann, J., 2010, Pietismus und Orthodoxie. Gesammelte Aufsätze III, Mohr Siebeck, Tübingen.

Ward, W.R., 2002, The Protestant evangelical awakening, Cambridge University Press, Cambridge. 